\title{
Bioavailability of Albendazole and its Metabolities in Plasma of Pangasianodon hypophthalmus with High Performance Liquid Chromatography
}

\author{
Showkat Ahmad Dar ${ }^{1 *}$, Vipin Nautiyal ${ }^{1}$, Vikas Phulia ${ }^{2}$, Subodh Gupta $^{1}$, \\ Primal Sardar ${ }^{1}$ and N.P. Sahu ${ }^{2}$ \\ ${ }^{1}$ Division of Fish Nutrition, Physiology, and Biochemistry, Central Institute \\ of Fisheries Education, Mumbai- 400061, India \\ ${ }^{2}$ GADVASU Ludhiana, Punjab-141004, India \\ *Corresponding author
}

\section{A B S T R A C T}

Keywords

Albendazole, HPLC,

Pangasianodonhypophthalmus, Maximum concentration $\left(\mathrm{C}_{\max }\right)$, Retention Time (RT).

Article Info

Accepted:

21 June 2017

Available Online:

10 August 2017
In the present experiment the depletion profile study of Albendazole and its metabolites (ABZSO and $\mathrm{ABZSO}_{2}$ ) were carried out in the plasma of Pangasianodon hypophthalmus. The experiment consists of three treatment groups and control. A $20 \mathrm{mg} / \mathrm{kg}$ body weight dose of ABZ was given through intraperitoneal, intramuscular and orally respectively to the three treatment groups while no drug was given to control group. The blood samples were collected at $0.5,1,2,4,8,12,24$, and $48 \mathrm{~h}$ intervals to determine the ABZ, ABZSO and $\mathrm{ABZSO}_{2}$ using High Performance Liquid Chromatography (HPLC) having C-18 reversed-phase analytical column. The samples were processed by mobile phase of Methanol-Water (60:40) at a constant flow rate of $1 \mathrm{ml} / \mathrm{min}$ and detected at $295 \mathrm{~nm}$ using a UV/Visible detector. The drug was detected in the plasma of orally given treatment group only. The Maximum concentration $\left(C_{\max }\right)$ of ABZ $3.461 \pm 0.06 \mu \mathrm{gml}^{-1}$ found at $8 \mathrm{~h}$ $\left(\mathrm{T}_{\max }\right)$ and retention time $(\mathrm{RT})$ of 23.88 minutes. For ABZSO Maximum concentration $\left(\mathrm{C}_{\max }\right)$ detected was $0.037 \pm 0.009 \mathrm{gml}^{-1}$ at $8 \mathrm{~h}\left(\mathrm{~T}_{\max }\right)$ with $\mathrm{RT}$ of 5.61 minutes and $\mathrm{ABZSO}_{2} \mathrm{C}_{\max }$ found was $0.023 \pm 0.007 \mu \mathrm{gml}^{-1}$ at $12 \mathrm{~h}\left(\mathrm{~T}_{\max }\right)$ with RT of 19.4 minutes. The concentration of metabolites reached to the levels of negligible after $48 \mathrm{~h}$. The present study reveals that giving ABZ through orally is efficient method for treatment of helminth infections in fishes.

\section{Introduction}

Albendazole (ABZ, [5-(propylthio)-1Hbenzimidazol-2-yl]-carbamate), is potent broad spectrum anthelmintic widely used for the treatment of Tapeworms, liver flukes, lung and gastrointestinal round worms in mammals (McKellar and Scott 1990).

The albendazole (ABZ) given is readily absorbed from the gut and through oxidation converted into its different metabolites, albendazole sulfoxide (ABZSO) major active metabolite, albendazole sulfone $\left(\mathrm{ABZSO}_{2}\right)$, and albendazole 2-aminosulfone (ABZ-2$\mathrm{NH}_{2} \mathrm{SO}_{2}$ ) (Gottschall et al., 1990). Albendazole biotransformation metabolites have been studied in many animals dogs (Delatour et al., 1990), rabbits (Li et al., 1995), sheep (Chiap et al., 2000), goats (Delatour et al., 1991) and humans (Rawden et al., 2000). Albendazole acts either by disruption of energy metabolism in helminths (inhibition of fumarate reductase), or 
disruption of the polymerization of tubulin in cellular microtubules (Manger B, 1991).

In fishes, the Nematodes (Roundworms) are the most common parasites found in marine fishes (Hilderbrand et al., 1985). Helminths infections are quite common in both feral and cultured fish (Petrushevski and Shulman, 1961). Freshwater and brackish water fishes are affected with huge infections in predatory fish, particularly those fish species which are utilizing fish as intermediate or transient hosts (Paperna et al., 1996). Jadhav (2010) reported that most host belonging to catfish families Schilbeidae, Bagridae, Heteropneustidae, Siluridae, Mastacembelidae, and Clariidae have been reported as definitive hosts of cestodes. Catfishes are significant fish fauna of wetlands and are economically vital as a food source of high nutritive value. Catfish of the family Pangasiidae especially Pangasianodon hypophthalmus is one of the promising species for aquaculture because of its omnivorous feeding habit, adaptability to crowded conditions, hardiness and a good market. $P$. hypophthalmus has immense economic importance in many countries of South and Southeast Asia, including India, Bangladesh, Thailand, Vietnam, and Malaysia.

Albendazole is extensively used in ruminants to treat gastrointestinal helminths (McKellar et al., 2002; Gokbulut et al., 2000) but there are reports that $\mathrm{ABZ}$ is also used in fish antiparasitic infections (Schmahl and Benini, 1998; Tojo et al., 1992). The pharmacokinetic study of ABZ was carried out in humans (Mirfazaelian et al., 2000) and sheep (Cristòfol et al., 1998). While in fishes the depletion of ABZ and its metabolites after oral administration in rainbow trout, and Atlantic salmon has been studied by (Shaikh et al., 2006). Reverse-phase high-performance liquid chromatography (HPLC) is one of the important analytical methods for determination of ABZ and its derivatives in the plasma. Albendazoleas widely used in veterinary medicine, so the literature also reports methods for the determination of residues of $\mathrm{ABZ}$ and its metabolites in milk (De Ruyck et al., 2000), ovine plasma (Chiap et al., 2000) and in human plasma (Garcia et al., 1999). But in the case of fishes, limited research is carried out for determination of $\mathrm{ABZ}$ in fish plasma, so the aim of the present study was to know the efficient method of giving $\mathrm{ABZ}$ to fish, further knowing the concentration of $\mathrm{ABZ}$ and its metabolites in fish plasma.

\section{Materials and Methods}

\section{Experimental design and Culture Conditions}

The experiment was conducted at wet laboratory of the Central Institute of Fisheries Education. About 120 fishes of $P$. hypophthalmus (average weight $100+30 \mathrm{~g}$ ) were obtained from mahad fish centre, Maharashtra. The fish were allowed to acclimate for two methods by feeding a drugfree commercial diet. Mean water temperature, $\mathrm{pH}$ and dissolved oxygen were around $26 \pm 2.00^{\circ} \mathrm{C}, 7.4$ and $6.4 \pm 0.01 \mathrm{ppm}$, respectively during the experimental period. On the day before drug administration, the fish were not fed. The experiment was carried out on 12 tanks with 10 fishes in each tank.

The tanks were kept in four groups with three tanks in each group. Among these, first group received intra peritoneal injection of $\mathrm{ABZ}$ of $20 \mathrm{mg} / \mathrm{kg}$ body weight, second group received intra muscular injection of ABZ of $20 \mathrm{mg} / \mathrm{kg}$ body weight, whereas, third group was given an oral dose of $\mathrm{ABZ}$ of $20 \mathrm{mg} / \mathrm{kg}$ body weight and fourth group taken as control group. For injection, ABZ was dissolved in DMSO and for oral dose, $\mathrm{ABZ}$ suspension was made in $0.5 \%$ carboxy methyl cellulose (CMC). 


\section{Sampling}

Blood was collected from each group through caudal vein at $1 \frac{1}{2} \mathrm{~h}, 1 \mathrm{~h}, 2 \mathrm{~h}, 4 \mathrm{~h}, 8 \mathrm{~h}, 12 \mathrm{~h}, 24 \mathrm{~h}$, and $48 \mathrm{~h}$. Blood collected into EDTA coating tubes and centrifuged at $2000 \mathrm{rpm}$ at $4^{\circ} \mathrm{C}$ for 20 minutes. After centrifugation supernatant was collected and freezed immediately at $-20^{\circ}$ $\mathrm{C}$ until further analysis. Each plasma sample collected was analysed for ABZ, ABZSO and $\mathrm{ABZSO}_{2}$ concentrations which was measured by high performance liquid chromatography (HPLC) technique.

\section{Sample preparation and HPLC analysis}

Two ml methanol was added to aliquots of plasma $(400 \mu \mathrm{l})$ to precipitate protein. After vortex mixing for five minutes, sample were centrifuged at $3000 \mathrm{~g}$ for $10 \mathrm{~min}$ and filtered through a nylon $0.22-\mu \mathrm{m}$ filter. $30 \mu \mathrm{l}$ aliquots of the filtered fractions were injected into the HPLC for further analysis

\section{Instrumentation and chromatographic conditions}

An HPLC system consisting of binary HPLC pump (Waters 1525), automatic sampler (Waters 2707). A mobile phase of MethanolWater $(60: 40)$ at a constant flow rate of 1 $\mathrm{ml} /$ minute was employed. Analysis was performed on a sunfire ${ }^{\mathrm{TM}}$ prep silica column $(250 \mathrm{~mm} \times 4.6 \mathrm{~mm}, 5.0 \mu)$.

The samples were measured at $291 \mathrm{~nm}$ using a UV/Visible detector (Water 2489) and data were analyzed with Water Breeze $^{\mathrm{TM}} 2$ integrator system. ABZ, ABZSO and $\mathrm{ABZSO}_{2}$ were purchased from sigma-Aldrich, India. All chemicals were of HPLC grade.

\section{Standard solution preparation}

Standards of different concentration were prepared in methanol. Working standard solution was in the range of $10 \mu \mathrm{g} / \mathrm{ml}-0.05$ $\mu \mathrm{g} / \mathrm{ml}$ for each $\mathrm{ABZ}, \mathrm{ABZSO}$ and $\mathrm{ABZSO}_{2}$.

\section{Results and Discussion}

\section{Calibration curves}

The linearity of the detector response for the compounds was evaluated by injecting a total of 10 working standards solution of various concentrations. The calibration curves are given in of $\mathrm{ABZ}, \mathrm{ABZ}-\mathrm{SO}$ and $\mathrm{ABZ}-\mathrm{SO}_{2}$ in figure 1.

\section{Concentration of ABZ, ABZSO and $\mathrm{ABZSO}_{2}$ in plasma}

For oral treatment the parent drug $\mathrm{ABZ}$ was detected in plasma up to $48 \mathrm{~h}$. The retention time for $\mathrm{ABZ}$ was found at 23.507 whereas for $\mathrm{ABZSO}$ and $\mathrm{ABZSO}_{2}$ the retention times are 5.545 and 16.952 respectively shown in figure 2. The depletion profile of ABZ, ABZ-SO and $\mathrm{ABZ}-\mathrm{SO}_{2}$ from the drug plasma is shown in figure $3(\mathrm{~A} \& \mathrm{~B})$. The highest concentration of plasma ABZ $3.46 \mu \mathrm{g} / \mathrm{ml}\left(\mathrm{C}_{\max }\right)$ was found at 8 $\mathrm{h}\left(\mathrm{T}_{\max }\right)$. ABZSO and $\mathrm{ABZ}-\mathrm{SO}_{2}$ was also detected upto $48 \mathrm{~h}$. For ABZSOC $_{\max }$ was $0.037 \mu \mathrm{g} / \mathrm{ml}$ at $8 \mathrm{~h}\left(\mathrm{~T}_{\max }\right)$ whereas for $\mathrm{ABZSO}_{2}, \mathrm{C}_{\max }$ was $0.023 \mu \mathrm{g} / \mathrm{ml}$ at $12 \mathrm{~h}$ $\left(\mathrm{T}_{\max }\right)$.

The ABZSO is active metabolite of ABZ in $P$. hypophthalmus. Concentration of ABZ-SO in plasma was higher than $\mathrm{ABZSO}_{2}$ concentration. For intramuscular and intraperitoneal treatments, $\mathrm{ABZ}$ in DMSO was administered to fish but neither ABZ nor its metabolites were detected in any of these two treatments. Moreover, high mortality was reported in the fishes given intramuscular and intraperitoneal treatments with DMSO. Hence, it can be concluded that the antihelminthic drug $\mathrm{ABZ}$ shows best results when it is given as oral treatment to the target animal. 
Fig.1 The calibration curve of of ABZ, ABZ-SO and ABZ-SO $\mathrm{S}_{2}$ standards solution of various concentration range from $10 \mu \mathrm{g} / \mathrm{ml}$ to $0.05 \mu \mathrm{g} / \mathrm{ml}$

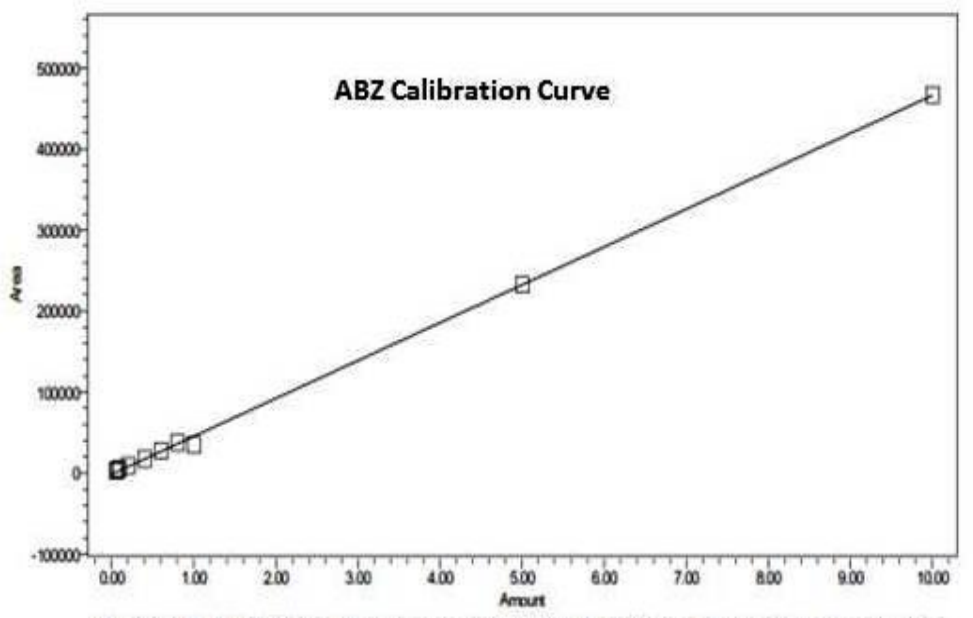

Name: ABZ; Time: 23.770; Fit Type: Linear (1s Order), $R: 0.999684 ; R^{2} ; 0.999367$ : Equation: $Y=$ - $4.68 \mathrm{e}+004 \times-1.42 \mathrm{e}+003$;

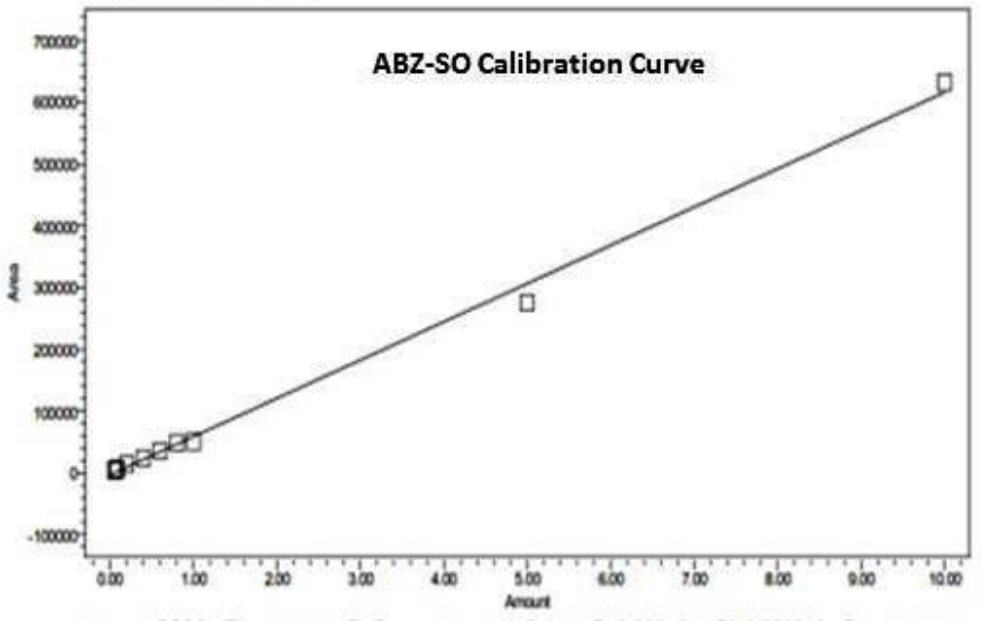

Name: AB2SO: Time: 5.545; Fit Type: Linear (1s Ondert. Re 0.998124: $R^{2}, 0.996252 ;$ Equation: $Y=$ $6.20 \mathrm{e}+004 \times-3.31 \mathrm{e}+003$ :

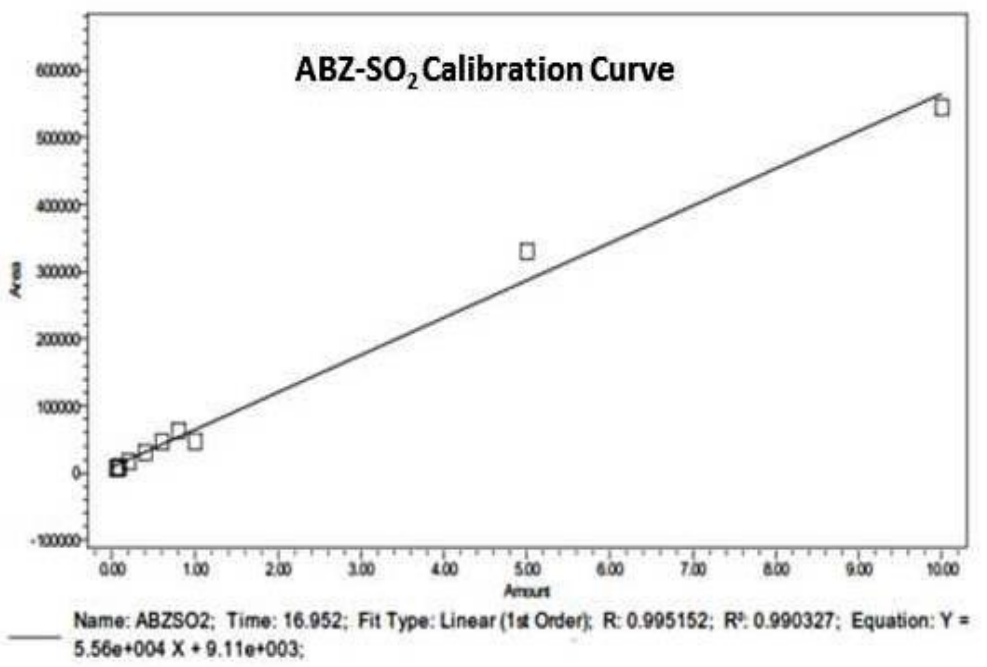


Fig.2 Chromatographs of ABZ, ABZ-SO and ABZ-SO $\mathrm{S}_{2}$ detected in plasma sample collected at with different Retention times

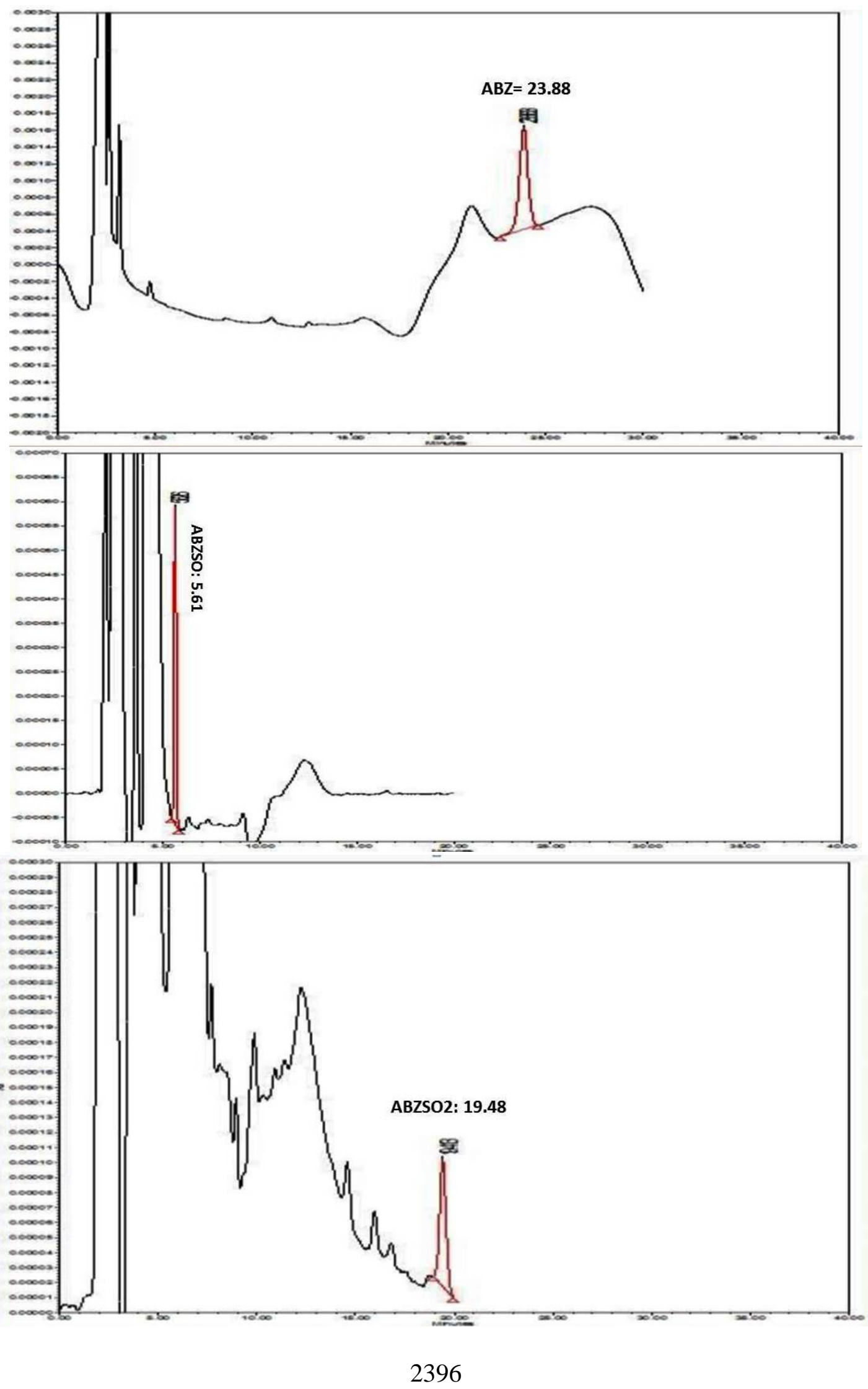


Fig.3A Plasma depletion concentration of ABZ vs time period following oral ABZ administration. Each time point $(n=3)$ represent the mean $\pm S E$, with significant difference $(\mathrm{p}<0.05)$ at different time intervals

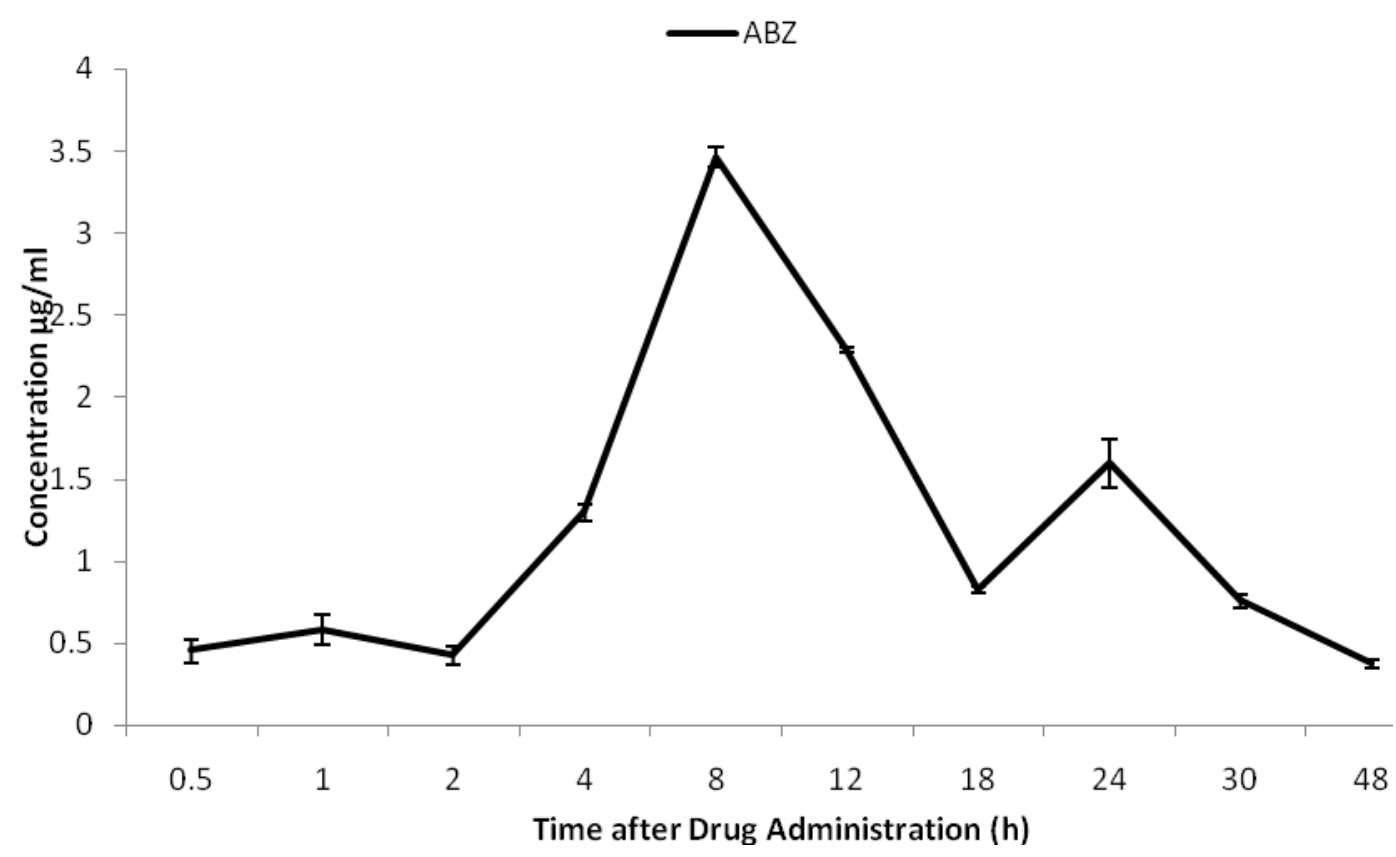

Fig.3B Plasma depletion concentration of $\mathrm{ABZSO}$ and $\mathrm{ABZSO}_{2}$ vs time period concentration after oral $\mathrm{ABZ}$ administration. Each time point $(n=3)$ represent the mean $\pm S E$, with significant difference $(p<0.05)$ at different time intervals

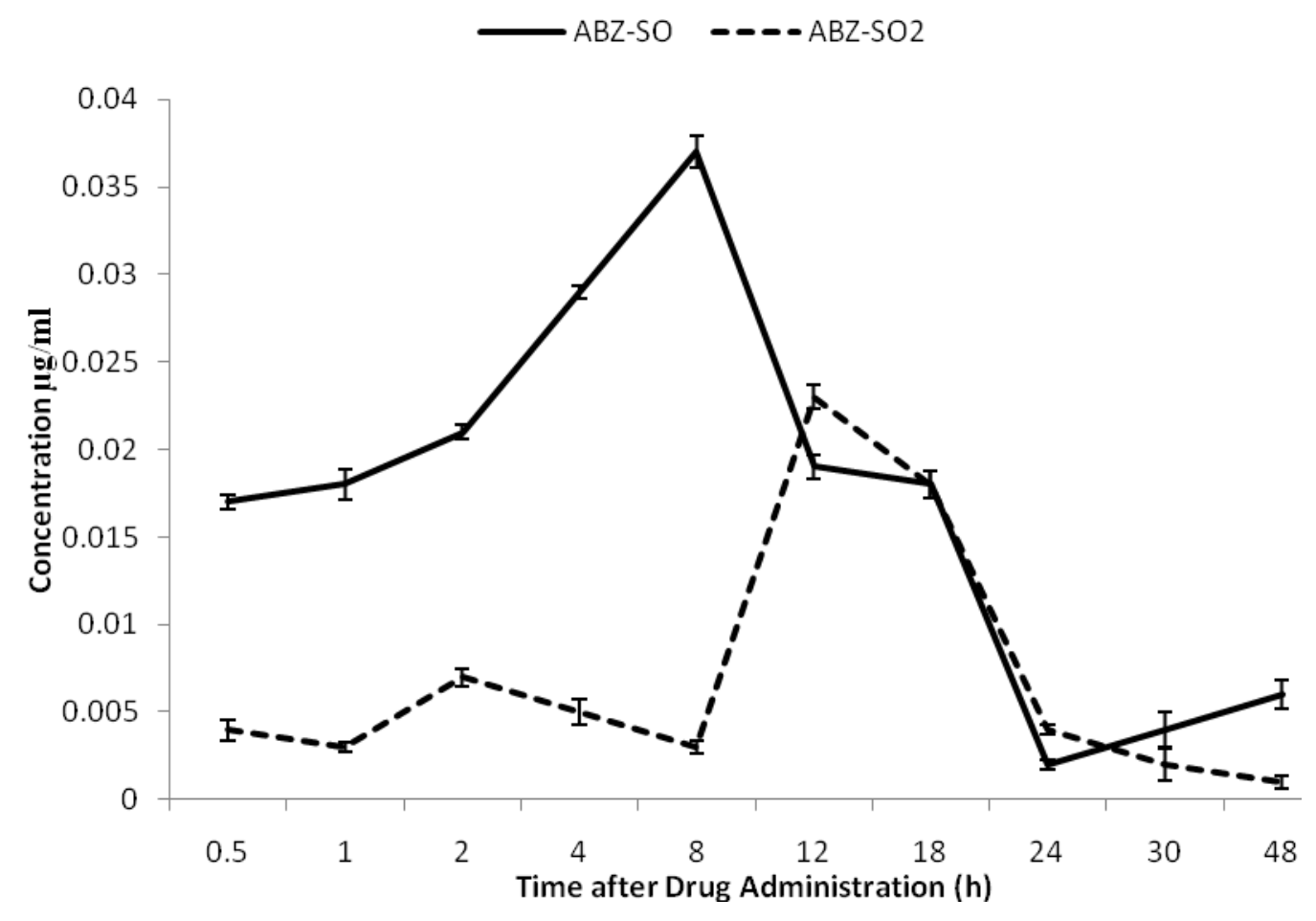


In the present study, the pharmacokinetics of ABZ and its metabolites was done using HLPC to detect the concentration in plasma. Our study was comparable with the earlier study of Polo et al., (2013) who have performed the HPLC assay for the quantification of Albendazole and metabolites,] ABZSO and ABZSO2 in plasma of mice. In this study calibration graphs containing in the range of 0.05 to $10 \mathrm{ugml}-1$ of ABZ, ABZSO and ABZSO2 with calibration curves were linear $(\mathrm{r} 2 \geq 0.990)$ which is similarly reported by (Shah et al., 2014; Shaikh et al., 2003). A $20 \mathrm{mg}$ single dosage was given through oral intubation, intramuscular and intraperitoneal, the drug was found in oral dose only. The results are comparable with Cai et al., (2007) who after giving the $\mathrm{ABZ}$ dose to rabbits oral as well as intraperitoneally found ABZ level were significantly higher after oral administration. The possibility of ABZ in rabbits may be due to a higher dosage of $150 \mathrm{mg}$ given by Cai et al., (2007) comparable to our study giving only $20 \mathrm{mg} /$ body weight of fish. Further no reports of ABZ through intramuscular and intraperitoneally are available in fishes. In the present study, the concentration of $\mathrm{ABZ}$ and its metabolites were investigated up to 48 hours. These results are comparable with the of Shaikh et al., (2003) who found that ABZ was depleted by $24 \mathrm{~h}$ in rainbow trout and tilapia by $48 \mathrm{~h}$ in salmon, respectively. The maximum concentration (Cmax) of $\mathrm{ABZ}$ $3.4614 \mu \mathrm{g} / \mathrm{ml}$ was found at $8 \mathrm{~h}$ which is comparable with the earlier work of Mckellar et al., (1995) who found maximum concentration (Cmax) $1.27 \pm 0.27 \mu \mathrm{g} / \mathrm{ml}$ at 8 $\mathrm{h}$ (Tmax) in 8 month old lambs.For ABZ-SO maximum concentration (Cmax) of 0.037 $\mu \mathrm{g} / \mathrm{ml}$ was found at $8 \mathrm{~h}$ (Tmax) which is comparable with results of Goudah A (2003) who also found highest concentration ABZ$\mathrm{SO}$ at $7.7 \mathrm{~h}$ after treatment in sheep. Further, the maximum concentration (Cmax) 0.023 $\mu \mathrm{g} / \mathrm{ml}$ of ABZ-SO2 at $12 \mathrm{~h}$ (Tmax) which is very much similar to Gokbulut et al., (2006) who found maximum concentration (Cmax) $0.04 \pm 0.00 \mu \mathrm{g} / \mathrm{ml}$ at $8 \mathrm{~h}$ in donkeys. The concentration of parent compound $\mathrm{ABZ}$ and its metabolites ABZ-SO and ABZ-SO2 decline as the time increase from the point of administration. The concentration of parent compound was highest comparable to $\mathrm{ABZSO}$ and ABZSO2 in fish plasma.

In conclusion, the present study reveals that oral treatment is the best method for administration of Albendazole dosage for the helminthic diseases. Further, the depletion of Albendazole in fish takes near about $48 \mathrm{~h}$ for the effective removal of the drug from the plasma of fish. Hence, providing sufficient time for the removal of parasites from the fishes.

\section{References}

Cai, Z., Galettis, P., Lu, Y., Morris, D. L., and Pourgholami, M. H. 2007. Pharmacokinetics of Albendazole in New Zealand White Rabbits: Oral versus Intraperitoneal Administration. 422, 417-422.

Chiap, P., Evrard, B., Bimazubute, M.A., de Tullio, P., Hubert, P., Delattre, L. and Crommen, J. 2000. Determination of albendazole and its metabolites in ovine plasma by liquid chromatography with dialysis as an integrated sample preparation technique. Journal of Chromatography. A. 870, 121-134.

Cristofol, C., Virkel, G., Alvarez, L., Arboix, M. and Lanusse C.E. 2000. Comparative disposition of ricobendazole enantiomers after intravenous and subcutaneous administration of a racemic formulation to calves. Biopharm Drug Dispos. 21, 303-11.

De Ruyck. H., Van Renterghem, R., and De Ridder, H. 2000. Determination of 
anthelmintic residues in milk by high performance liquid chromatography Food Control 11, 165-173.

Delatour, P. Garnier, F., Benoit, E. and Caude, I. 1991. Chiral behaviour of the metabolite Albendazole sulphoxide in sheep, goats and cattle. Res. Vet. Sci. $50,134-138$.

Delatour, P., Benoit, E., Lecbenet, J. and Besse, S. 1990. Pharmacokinetics in sheep and cattle of Albendazole administered by an intraruminal slow release capsule. Res. Vet. Sci. 48, 271275.

Garcia, J.J., Bolas-Fernandez, F., Torrado, J.J. 1999. Quantitative determination of albendazole and its main metabolites in plasma, J. Chromatogr. B. 723, 265271.

Gokbulut, C., 2000. Pharmacokinetic disposition, faecal excretion, metabolism and chirality of anthelmintic drugs in horses. Ph.D. Thesis, University of Glasgow, Faculty of Veterinary Medicine, Department of Pharmacology. Glasgow, Scotland, UK.

Gokbulut, C., Cirak, V.Y. and Senlik, B. 2006. Plasma disposition and faecal excretion of netobimin metabolites and enantiospecific disposition of albendazole sulphoxide produced in ewes. Vet Res Communs. 30, 791-805.

Gottschall, D., Theodorides, V., and Wang, R. 1990. The metabolism of benzimidazole anthelmintics. Parasitol. 6, 118-124.

Goudah, A., 2003. Aspects of the pharmacokinetics of Albendazole Sulphoxide in Sheep. Vet. Res. Commun. 27: 555-566.

Hilderbrand, S. R., Price, J., Olson, R. E., 1985."Parasites in marine fishes, questions and answers for seafood retailers," SG Publication, Oregon State University Extension Service, Oregon State University, Corvallis, Ore, USA

Jadhav, B.V., 2010. Survey of tapeworms from Aurangabad region. Records of the Zoological Survey of India: A Journal of Indian Zoology. 110, 107-114.

Kitzman, D., Cheng, K.-J., Fleckenstein, L. 2002. HPLC assay for albendazole and metabolites in human plasma for clinical pharmacokinetic studies. Journal of Pharmaceutical and Biomedical Analysis. 30, 801-813.

Li, Z., Chen, C., Ai, D., Wang, C., Li, J., Qi, Y.,Cao, J. 2012. Pharmacokinetics and tissue residues of hydrochloric acid Albendazole sulfoxide and its metabolites in crucian carp (Carassius auratus) after oral administration. Environmental Toxicology and Pharmacology. 33, 197-204.

Manger, B.R., 1991. Anthelminthics. In: Veterinary Applied Pharmacology and Therapeutics, 5 th edn. Bradner, G.C., Pugh, D.M., Bywater, R.J. and Jenkins, W.L. (eds), Bailliere Tindall, London, pp. 513-548.

McKellar, Q., and Scott, E., 1990. The benzimidazole anthelmintic agents $-\mathrm{a}$ review. J.Vet. PharmacolTherap. 13, 223-247.

McKellar, Q.A., Coop, R.L. and Jackson, F., 1995. The pharmacokinetics of albendazole metabolites following administration of albendazole albendazole sulfoxide and netobimin to one-month and eight-month-old sheep. Int J Parasitol. 25:1207-12.

McKellar, Q.A., Gokbulut, C., Benchaoui, H.A. and Muzandu, K.M., 2002. Fenbendazole pharmacokinetics, metabolism and potentiation in horses. Drug Metabolism and Disposition. 30, 1230- 1239.

Mirfazaelian, S., Dadashzadeh, M.R. and Rouini, A. 2000. high performance liquid chromatography method for simultaneous determination of albendazole metabolites in human serum J. Pharm. Biomed. Anal. 30, 
1249-1254.

Paperna, I., 1996. "Parasites, infections and diseases of fishes in Africa-an update," CIF Technical Paper FAO, Rome, Italy, 31, 21-34.

Petrushevski, G., K., and Shulman, S., 1961. The parasitic diseases of fishes in the natural waters of the USSR Parasitol. Of Fishes. Oliver and Boyd,Edinburgh/London, pp. 299-319.

Polo, S. R., Torrado, J., Bolas, F., and Torrado, S. 2013. A Selective and Simple RP- HPLC Assay To Quantify Albendazole Metabolites in Plasma. Journal of Liquid Chromatography \& Related Tech. 4, 37-41.

Rawden, H.C., Kokwaro, G.O., Ward, S.A. and Edwards, G. 2000. Relative contribution of cytochromes P-450 and flavin-containing monooxygenases to the metabolism of albendazole by human liver microsomes. British Journal of Clinical Pharmacology. 49, 313-322.

Schmahl, G., and Benini, J. 1998. Treatment of fish parasites. 11. Effects of different benzimidazole derivatives (albendazole, mebendazole, fenbendazole) on Glugea anomala

1887
(Microsporidia): ultrastructural aspects and efficacy studies. Parasitology Research. 6, 41-49.

Shah, S.D., Prasanna, P., Jaina, H.K., and Upadhyaya U. M., 2014. Journal of Taibah University for Science 8, 54-63.

Shaikh B., Rummel N., Gieseker C., Serfling S., and Reimschuessel R. 2003. Metabolism and residue depletion of Albendazole and its metabolites in rainbow trout, tilapia and Atlantic salmon after oral administration.Journal of Veterinary Pharmacology and Therapeutics. 26, 421-427.

Shaikh, B., Rummel, N., Geiseker, C. and Reimschuessel, R. 2006. Metabolism and depletion of albendazole in the muscle tissue of channel catfish following oral treatment. Journal of Veterinary Pharmacology and Therapeutics. 51, 3254-3259.

Tojo J., Santamarina M. T., Ubeira F. M., Estevez J., and Sanmartin M. L. 1992. Anthelmintic activity of benzimidazoles against Gyrodactylus sp. Infecting rainbow trout Oncorhynchus mykiss Diseases of aquatic organism Dis. aquat. Org. 12, 185-189.

\section{How to cite this article:}

Showkat Ahmad Dar, Vipin Nautiyal, Vikas Phulia, Subodh Gupta, Primal Sardar and Sahu, N.P. 2017. Bioavailability of Albendazole and its Metabolities in Plasma of Pangasianodon hypophthalmus with High Performance Liquid Chromatography. Int.J.Curr.Microbiol.App.Sci. 6(8): 2392-2400. doi: https://doi.org/10.20546/ijcmas.2017.608.283 